\title{
ХРИШЋАНСКА НАЗАРЕНСКА ЗАЈЕДНИЦА У СРБИЈИ
}

\section{Сажетак}

У раду се бавимо протестантском доминацијом, која је у Србији регистрована као Хришћанска назаренска заједница, а позната је као назарени. Упознајемо се са настанком ове религиозне заједнице, ширењем на овим просторима, његовим члановима, правилима којих се придржавају чланови, најважнијим догматским принципима које поштују као и репресијама које су трпели од стране државе. Такође у раду анализирамо сазнања која има шира заједница о назаренима на основу спроведене анкете.

Кључне речи: Хришћанска назаренска заједница, назарени, верска заједница, догматика, анкета, Србија

На Филолошком факултету у Београду 13. марта 2018. године у оквиру предмета Савремене студије културе др Ендрју Смит (Andrew J. M. Smith) са Емпорија државног универзитета у Канзасу је као гостпредавач одржао врло интересантно и упечатљиво предавање о Генеалогији и породичној историји. Професор је указао на чињеницу колико је важно упознати своју породичну прошлост и породичну историју да би боље упознали себе и разумели своје животне одлуке, своје родитеље и претке и оставили писане трагове о породичној историји за генерације које долазе, будући да, по његовим речима, нема неинтересантних људи и породица а знање се губи уколико није сачувано у писменом облику - публиковано.

Предавање проф. Смита је оставило снажан утисак на нас, те нас је мотивисало да се позабавимо својом породичном прошлошћу кроз рад о једној мање познатој религијској верској заједници на овим просторима која се зове Хришћанска назаренска заједница или краће назарени. Како у својој породичној генеалогији имамо претке и рођаке који су били и јесу чланови ове заједнице, као и оне који су и данас у врху ове заједнице, упознати смо са правилима и обичајима и начи- 
ном живота ове заједнице (од давнина до данашних дана) и у блиским контактима смо са члановима (и у земљи и у иностранству) те немамо предрасуда према њима и желимо да објективно представимо њихов захтеван хришћански живот пун самоодрицања и проблема са којим су се сусретали током својих живота, њихов догмат. Поред тога, наша идеја је била да кроз једну кратку анкету проверимо степен базичне информисаности о овој хришћанској заједници и да анализирамо добијене резултате о односу шире заједнице према назаренима.

Назарени су први нови верски покрет који се појавио у Угарској после 16. века (Алексов, 2010: 11-12), а уједно и прва протестанска група која је стекла завидан број чланова међу српском, мађарском и румунском ${ }^{1}$ и немачком популацијом у тадашњој Јужној Угарској (Bjelajac, 2015: 41). Иако је настао у Швајцарској, у целој Угарској се брзо ширио већ од средине 19. века а посебно у вишенационалној Војводини, како међу другим народима² тако и међу Србима. Убрзо после појаве у Војводини, прелази у Србију, у Обреновац, одакле се шири у другим градовима као што су Београд, Смедерево, а потом и Алексаинац, Аранђеловац, Ниш, Јагодину, Крагујевац итд.

Назарене су карактерисали негирање свештенства, негирање крштења одојчади и свете тајне причешћа, уздржање од војне службе, политике, од полагање заклетве као и верска служба на свакодневном, разумљивом језику. Иако данас помало заборављени, назарени су у моменту највећег ширења крајем 19. века били у центру црквене ${ }^{3}$ и политичке пажње. С друге стране они су били и инспирација писцима тога доба - мађарским: Карољу Етвешију и Мору Јокаију, српским: Јовану Јовановићу 3 мају $^{4}$ и Сими Матавуљу 5 , чешком Јарославу Хашеку као и великом Лаву Николајевичу Толстоју ${ }^{6}$ (Алексов, 2010: 12).

1 О Румунима назаренима видети: Ђурић-Миловановић, 2010.

2 О Русинима назаренима се говори у причи Назарен, видети: Константиновић, 1995.

3 О активностима против новог покрета је подробно писао Слијепчевић, 1943.

4 Јован Јовановић Змај је препевао, по Бјелајцу (2015:64), 56 песама за песмарицу Харфа Сиона, а осталих 250 је препевао Ђорђе Рајковић.

5 Симо Матавуљ је написао приповетку Нововерци, која се налази у зборнику приповедака Из разних крајева (1893, Мостар).

6 Постоје сведочанства да се Лав Толстој интересовао за активности назарена на нашим просторима, више о томе: Bjelajac, 2015: 53-54. 
Данас су они познати као Хришћанска назаренска заједница - краће назарени, како су и регистровани у Србији са седиштем у Новом Саду (Валентина Водника 12), у Америци се називају Апостолска хришћанска заједница а поред тога назива су фигурисали и други називи?.

Прича о назаренима је, како сведочи и Бјелајац (2015: 43), заправо прича о прогонствима ${ }^{8}$, о страху власти пред добронамерним, скромним и тихим грађанима који су уздрмали инертну верску и световну организацију привлачећи све више истомишљеника жељних изворних хришћанских начела, који су у пракси примењивали и сведочили Јеванђеље својим животом, не само декларативно.

Оснивач назаренства је Самуило Хенрих Фрелих 9 , рођен 1803. у Бругу, Швајцарска (кантон Аграу), умро 1857. у Стразбуру. Као млад се школовао за калвинистичког свештеника, а 1823. уписује новоосновану базелску богословију. Прекретница у Фрелиховом животу је 1825. ускршњи распуст, који проводи у родном месту, где доживљава позив Божији за обраћање. Истога тренутка он одговара на позив, молитвено се обећавајући Богу на верност ${ }^{10}$. Године 1830. званична црква наређује Фрелиху да напусти свој положај и забрањује му се да се бави свештеничким послом. У априлу 1833. у Лајтвилу он оснива „Свету општину” са 33 члана, формирањем ове општине почиње историја назаренства. Све до своје смрти 1857. у Стразбуру Фрелих живи животом ревносног хришћанина, проводећи највећи део времена у духовним активностима - читању Библије и њеном проучавању, молитвама, писању и проповедном раду. Фрелих није само био успешан проповедник него и објављује књигу која постаје драгоцена за овај покрет под насловом $O$

7 Помињу се следећи називи што као паралелни у употреби, што описни а неки су и пејоративни: нововерци, назаренци, лазарени, покајници, бугери, новоназарени, верујући у Христа следбеници Христови, наследници Христови. Сматра се да су име добили по стиху из Новог завета «да ће се назарећанима звати» (Бјелајац 42).

8 Детаљно је о томе писао Слијепчевић, 1943.

9 Његово име истраживачи преносе на неколико начина, у назаренској заједници у Србији је прихваћено у верзији Самуило Фрелих (како срећемо и код Ђорђевић, 2003), код Бјелајца (2015: 43) је Самуел Фрелих (Samuel Heinrich Froehlich ili Fröhlich) а код Алексова Самјуел Хајнрих Фрелих (2010: 71). калвинистички пастор. Током наредних година долази у сукоб са сопственом верском заједницом по питању докринарних правила, као што је крштавање деце, због чега бива премештен (Ђорђевић, 2003: 12). 
односу верника и државне иркве. А још важнији догађај је појава првог издања Харфе Сиона 1837. збирке религиозних песама коју је приредио бирајући песме које су користили баптисти, реформате и лутерани. Публиковао је и своју аутобиографију. Харва Сиона је једна од најважнијих књига у животу сваког назарена (поред Библије ${ }^{11}$ од које се никад не раздвајају) кад је први пут објављена на српском језику изазвала је бурне реакције ${ }^{12}$.

Двојица мађарских шегрта, бравари ${ }^{13}$ Јанош Денкел и Јанош Кропачек ${ }^{14}$ одлазе у Швајцарску касних 30-тих година 19. века да би тамо усавршили занат, тамо су се преобратили под утицајем Фрелихових проповеди. Године 1839. они се враћају у Пешту где са учењем Фрелиха упознају деветнаестогодишњег Лајош Хенчеја ${ }^{15}$, који је највише допринео успостављању нове верске заједнице у Угарској међу Мађарима, његове заслуге су препознате и због тога бива прозван „угарски Фрелих" (Алексов, 2010: 77). Он је уједно и први припадник нове верске заједнице у Угарској који је крштен, после преобраћења 1840. (Алексов, 2010: 77-78). Након годину дана од крштења 1841. Хенчеј почиње да пише своје Вјерују у којем је утемељио главне принципе нове верске заједнице. Део ове књиге је написан у облику писама у којим јача веру и снагу своје браће и сестре у вери. У недостатку новаца за штампање књига остаје у рукопису, коју су његови следбеници преписивали и размењивали између себе. Остаје непознато је да ли је Хенчеј у то доба био упознат са неким Фрелиховим списима. Алексов (2010: 79) пише да Хенчеј схвата да мора да оде у Швајцарску да се лично сусретне са Фрелихом, будући да је делио с њим исте религијске погледе и исту веру, одлази пешке у Швајцарску и убрзо потом се разбољева од туберкулозе. У Швајцарској је и преминуо 1844.

Са севера назаренство почиње да се шири и међу Србима настањеним на просторима Аустро-Угарске, а неколико година касније и у Србији (Ђорђевић, 2003: 12). Различити извори доносе различите

Назарени користе Библију у класичном преводу Даничић/Караџић.

Прво издање препева Харфе Сиона на српском је публиковано 1876. О нападима на Јована Јовановића Змаја и његовом односу према назаренима и цркви више у: Максимовић, 1911.

13 Бјелајац их назива кључарима (2015:47). 
податке о првим назаренима у Јужној Угарској. Бјелајац пише о првом назаренском обраћенику Јожефу Тоту који је постао верник 60-тих година 19. века у Суботици (2015:49). Бојан Алексов помиње Јожефа Хорвата Киша као обраћеника из калвинизма који делују међу Србима још од 1860. (2010: 62). Тај исти Јожеф Хорват Киш упућује посланицу мађарским назаренима у Пачир 1861. у којој их обавештава да се у Новом Саду скупштине одржавају без сметњи (Bjelajac, 2015: 50). Ови подаци нам доказују да је назаренство присутно и пре 1860. у данашњој Војводини и упућују нас на ранији период и доводе до првог назаренског апостола или епископа у Јужној Угарској - до школованог католика Иштвана Калмара ${ }^{16}$ којег помиње Алексов (2010: 86). Калмар је један период свог живота провео у затвору, где се преобратио слушајући утамничене назарене. Након пуштања на слободу Калмар је постао најзаслужнији за ширење назаренства у Јужној Угарској (Алексов, 2010: 87), он, такође, преводи Фрелихове радове и Нови завет на мађарски. Године 1854. Калмар оснива малу заједницу у Пешти, које су власти откриле и растуриле а њега протерују у родни Пачир. Пачир постаје дом прве назаренске заједнице у Јужној Угарској. Одатле се назаренство шири у суседне градове у Суботицу, Мако, Сегедин, Бечеј, Мали Иђош, Фекетић, Кулу, Мол, Нови Сад, Темишвар.

Други извори говоре о првим назаренима на овим просторима који се појављују око 1865. у Сремским Карловцима ${ }^{17}$. Први проповедник назаренства је у овим крајевима био виноградар Мато Ребић, он се упознао са назаренством преко припадника ове заједнице у Пачиру (Ђорђевић, 2003: 13).

Први подаци о појави назаренства у Краљевини Србији се односе на 1872. Реч је о писму обреновачког поштара Илије Марковића, упућеног митрополиту Михајлу, у коме он Павла Росића означава као

16 Пал Биро, тадашњи калвинистични свештеник у Бачкој и Калмаров познаник, писао је о њему и забележио је да је Калмар након студија теологије и права, постао цивилни службеник. Како је говорио српски, током револуције 1848-49. био је мађарски шпијун који је шпијунирао српске јединице које су за рачун Беча ратовале против мађарске војске, због тих активности је након пропасти револуције завршио у затвору у Бечу. После неког времена је пребачен у пештански затвор, тамо се упознаје са назаренским учењем слушајући кроз кључаоницу затворене назарене (који су тамо утамничени 50тих година 19. века). То је код њега довело до преобраћања (Алексов, 2010: 86-87). 
првог проповедника. Прве Росићеве присталице су биле женске особе, са којима је заједница одлазила у Аустрију - сремско село Прогар, у назаренску Скупштину на богослужење. Државне власти су већ на самом почетку према Росићу и његовим присталицама примењивали репресивне мере у чијој примени је учествовао и црквени апарат (свештеници су заједно са наоружаним полицајцима стајали на обалу не дозвољавајући присутнима да пређу реку) о чему пише Ђорђевић (2003:13). Алексов доноси више података о судбини Росића - власти га лишавају слободе, осуђују на једногодишњузатворску казну и протерују проповеднике који из Срема прелазе у Србију. Поједини назарени који су одбили да узму оружје били су осуђени на смрт, мада су били ослобођени смртне казне, назарени су тек почели да осећају невоље које ће их пратити током читавог следећег века (2010: 106-107). 36ог ових и сличних репресивних мера који ће пратити цело „златно доба“18 назаренства, у протест су се укључиле неке европске земље, као што је енглеска влада али и странци који су живели у Србији као што је био и Мекензи ${ }^{19}$, који се залагао за права назарена и а њихове породице је материјално помагао док су им мужеви лежали по затворима (Bjelajac 2015: 62). Оно на шта су странци скретали пажњу Србији је члан 35. Берлинског уговора из 1878. који је обавезивао нове балканске државе на потпуно поштовање слободе вероисповести.

\section{Хришћанска назаренска заједница - религиозне поставке (догматика)}

Самуило Хенрих Фрелих после преобраћења, након Божијег позива за измену грешног живота и обећања Богу на верност, пола-

18 Период од појаве првих назарена па до Првог светског рата Ђорђевић (2003: 14) назива узлазним добом назаренства или његовим златним добом. Ђорђевић сматра да се већ између два светска рата примећује стагнација а после Другог светског рата оштрија стагнација овог покрета.

19 Франсис Макензи, рођен 1833. као син шкотског барона, поморски официр и богати племић. У Србију долази током српско-турског рата 1876. у намери да помаже рањеницима на фронту, финансирао је изградњу путева и учествовао у сличним филантропским активностима. Касније се заинтересовао за протестанстке назарене у Србији (Bjelajac 2015: 66). 
же и испите и пролази рукоположење за свештеника. Његове ватрене проповеди већ од првих дана изазивају неодобравање званичне цркве у Швајцарској и завршавају се суспензијом. У проповедима он захтева, како бележи Алексов (2010: 74), духовну обнову и осуђује свакодневни живот житеља парохије који је био пун греха и верских преступе.

Од првих дана настанка ове религијске заједнице пред назарене су постављани високи хришћански циљеви исправног, моралног, радног и последично веома тешког живота пуног одрицања и страдања. Иако врло мирољубили, радни, вредни и тихи, назарени у Јужној Угарској и касније у Краљевини Србији, СФРЈ, СРЈ су доживљавали страшне репресије ${ }^{20}$ због прихватања идеје ненасиља - одбијања да се узме пушка у руке - тј. да се служи војска. Те репресије ${ }^{21}$ су трајале до периода кад је уведен закон о приговору савести и о цивилном служењу војске.

Поред ненасиља, друга важна доктринарна поставка је и Фрелихово усвајање гледиште анабаптиста - о некрштавању деце, те се крштење спроводи тек кад се доживљава потпуни унутрашњи преображај кандидата. Крштење је иначе код назарена чин од великог значаја, који обавља старешина (пандам највишег свештеног лица) потапањем/погружењем у воду будућег члана заједнице. Алексов пише о крштењима на отвореном (2010: 157) то се односи на раније периоде назаренске заједнице, будући да се у савременом добу крштење врши у оквиру молитвеног дома или скупштине како се зове «црква» назарена. У назаренску заједницу се искључиво примају (крсте) одрасле, пунолетне особе, које су преобраћене и које пролазе, пре крштења, процену духовног преображаја од стране заједнице, после исповести пред старешином. Сам чин крштења код назарена је, још једном да поменемо, велики догађај који је, чини се

20 Мушкарци назарени су због одбијања служења војске или узимања пушке у руке, како о томе говоре су осуђивани на дугогодишње затворске казне. Најчешће су казне, пример између два светска рата биле између 10 и 12 година. Међутим, мало се зна да су још од почетака ширења назаренског покрета припадници и верници - назарени били и убијани, вршена је егзекуција и како преноси Бјелајац најчешће су убијани Срби јер су припадали граничарским јединицама. Прва документа о томе се односе на 1875. кад се у Бачкој од три млада назарена, једног стрељали а друга двојица си умрла од батињања палицама, али су до последњег тренутка остали верни својој вери. Још два стрељања су забележена у Босни и Херцеговини (Bjelajac, 47-48). 
и најрадоснији догађај у заједници, то је догађај на који долазе други назарени (гости) из других скупштина у земљи и иностранства ${ }^{22}$. На служби приликом примања могу присуствовати неверни (сви они који нису назарени) али само у појединим деловима службе, док је остали део церемоније или како Ђорђевић назива иницијализације само за чланове назаренске скупштине.

Брачна заједница је за назарене светиња како и прописује хришћанство. Фрелихови следбеници одбацују брак скопљен у цркви јер томе претходи и црквено крштење, те сами развијају сопствене обичаје (Алексов, 2010: 158). Оно што је веома важно рећи је да се назарени смеју венчавати једино са припадницима своје заједнице, правило се није изменило до данашњих дана, а ако је члан венчан приступио назаренима потребно је и да брачни партнер приступи заједници. Њихова традиција која је актуелна и сада (посведочио старешина у Америци) је да се млади упознају на службама, религиозним излетима и сл. и кад се млади допадну једно другом, будући младожења прво старешини саопштава своју жељу да се жени ${ }^{23}$, старешина разговара са будућим паром и процењује њихову спремност за брак и све што брак носи собом, потом би и родитељи давали сагласност, затим би се заједница молила за њихову будућност и за Божији благослов, потом би се давала сагласност за брак. С друге стране и пар је требало јавно, по речима Алексова (2010: 158), да изрази своју љубав и одлучност да буде заједно и у добру и у злу. Свадбе нису пропраћене прославама, гозбама, нема поклона, мираза и сличних обичаја. Назаренске породице су многочлане а сваки облик прекида трудноће је незамислив јер би се тим чином нарушила воља Божија.

По сличном обрасцу скромности и умерености се одликују и сахране. Службу на сахрани обавља слуга (ниво свештеника) или старешина (поглавар) из локалне скупштине или са стране, од родбине се очекује суздржавање од плакања и туговања јер кад хришћанин мре престају нужде (стих из Харфе Сиона). Слуга би држао обично врло емоционално обојену проповед на сахрани а обавезно се погребна

22 У организовању крштења и примању и смештању гостију учествује читава заједница по својим могућностима и умећима.

23 Код назарена не постоји забављање у данашњем смислу речи. 
служба завршава појањима (певањем) из песмарице Харфа Сиона, која остављају трајан утисак на све присутне било које вере.

Иако се умногоме стриктно придржавају Библије, код назарена се није утемељио пост као обавезна појава на колективном ниво. Пост није нужан, тј. није обавезан облик аксезе примећује Ђорђевић (2003: 33).

Однос према крсту као симболу Исусовог страдања је негативан, назарени га не признају и не носе га, нити га стављају на гробна места, по томе се могу препознати гробови назарена. О томе пише Ђорђевић и каже да назарени сматрају да се крст као симбол хришћанства појавио у каснијим временима када хришћанство није више поседовало своје темељне изворне форме. Крст је и средство којим је мучен и убијен Христ, зато га назарени као изворни следбеници Христови, не могу прихватити за свој симбол (2003: 21).

Од осталих поставки како је уређен живот назарена треба напоменути и неколико следећих ствари: назаренима је забрањено полагање заклетве, они никад не смеју ни у ком случају да говоре неистину, не смеју да судским путем истерују правду, није им дозвољено гласање, никакав вид политичког ангажовања, не смеју да злослове, да псују, да непристојно говоре, да присуствују догађајима где има непристојних песама, славља ${ }^{24}$.

За назарене се лично спасење може остварити само кроз заједницу не може као индивидуално биће, велики грех је добровољно иступити из заједнице (Ђорђевић, 2003: 32-33).

Одевање је једна од социјалних одлика назарена по коме се разликују од других. Они се одевају скромно и умерено, мушкарци су се препознавали по шеширу који носе и оделу без кравате а жене по дугачким сукњама или хаљинама до чланака, и марама које носе не само на молитви. Мушкарци се обавезно кратко и уредно шишају, не носе браде. Жене морају да имају дугачку косу уређену у пунђу, не носе накит, ни венчани прстен, не смеју да се фарбају нити шминкају. У

24 Тако нпр. родитељ не би смео да присуствује општинском венчању своје деце или одласку у војску и полагању војне заклетве или сл. јер назарени то не признају. Једно од правила назарена је и немешање са другим људима, а присутво неком чину се поистовећује са одобравањем. 
Америци се строга правила одевања помало коригују у последње време, те жене могу да носе панталоне у свакодневном животу, могу да се повежу марамом само у скупштини (чак и неким ситнијим покривачем за главу који стоји на темену причвршћен шналицама) и да носе краћу косу а мушкарци не носе сви и увек одела и шешир (панталоне и кошуља су допуштени у Хришћанској апостолској цркви у Калифорнији).

Како је скромност врлина у понашању, одевању, тако је и у изгледу и уређењу молитвеног дома, стога нема живописања, украшавања, фресака, скулптура.

У Србији су молитвени назаренски домови изграђени по принципу да постоји посебан улаз за жене и мушкарце ${ }^{25}$. У молитвеном дому у Новом Саду (главна назаренска скупштина у Србији, налази се у Валентина Водника 12, а представник је Карло Хрубик) се налазе клупе а жене и мушкарци улазе са разних страна и редови клупа су одвојени по средини дома где се налази проповедаониоца а заправо мушкарци седе наспрам жена (одвојени пролазом и проповедаоноицом као централним делом скупштине). У самој сали се мушки и женски чланови заједнице не мешају иако су већином сви повезани родбинским или брачним везама.

Недеља ${ }^{26}$ је дан кад се верници окупљају у молитвеном дому ради служењ $а$ Богу и молитава. У Новом Саду ${ }^{27}$ и неким скупштинама у Америци, служба се одвија и пре и после подне са подневном паузом. У земуској скупштини је недељна служба једнократна као и у скупштини у Лос Анђелесу и у Немачкој. Одлазак на службу је обавезан, а верницима је то и највећа радост.

25 У Хришћанској апостолској цркви, као назаренској заједници у Америци (Лос Анђелес, Калифорнија), у којој су већином исељеници из ових крајева, иако је здање молитвеног дома наменски прављено, није се правила та дистинкција, тако да и мушкарци и жене улазе и излазе на исти улаз и врата. У унутрашњости молитвеног дома се налазе клупе, са десне стране седе жене а са леве мушкарци, између се налази пролаз који води напред до проповеднице и места где седе старешине, где се налази и хор.

Недеља је иначе за назарене посебно свет дан. Недељом се иде у скупштину на молитву, Богу је посвећен цео дан. У тај дан се не врше никакве друге активности у кући и ван ње: не пере се, не спрема се, ручак се припреми у суботу и сл. Верни (верници) су посебног расположења недељом јер се радују одласку у молитвени дом, а службе се не пропуштају.

27 У Новом Саду се службе одржавају и четвртком после подне. 
Код назарена не постоји плаћено свештенство, као ни детаљно прописано вршење службе. Сви назарени имају свој примарни посао од чега живе, у првим временима су били углавном и већином занатлије, сад има и назарена инжењера и научних радника, али се нпр. трговина сматра грехом. Жене су најчешће домаћице које одгајају многочлану породицу мада и оне могу да раде јер је рад високо вреднован. Назарени су познати по радној етици и поштењу, због чега су лако налазили послове кад су се исељавали у иностранство (то си најчешће биле Швајцарска, Немачка и Америка) између два светске рата и надаље.

Строга дисциплина, моралност, радна етика и помоћ ближњем су главне особине сваког назарена од давнина до данас.

\section{Анкета}

Анкета је првобитно била замишљена као детаљна анализа познавања Хришћанске назаренске заједнице са личном биографијом испитаника, поготово на тему религиозности и припадности хришћанској религијском мисли и цркви (црквама) са 60 питања. По савету колеге ${ }^{28}$ да је боље анкету направити краћом и језгровитом, кренули смо у прилагођавање постојећег упитника. Коначна верзија упитника је бројила упола мање питања и била је подељена на две групе питања - прва група која је за нијансу краћа се односила на питања из личне сфере да би се мало боље упознали са профилом испитаника - године живота, пол, место рођења и тренутног боравишта, школска спрема, а остала питања, из прве групе, су била везана за религиозност: да ли је испитаник крштен, да ли је религиозан, да ли чита религиозну литературу, да ли је он или она као члан неке верске организације упознат са активностима које организује његова црква (религијска заједница) и да ли у њој активно учествује или не.

Друга група питања је била у ужој вези са самим назаренима, односно сазнањима и односу ширих слојева друштва према њима и

28 Жарко Вељковић - класични филолог и аутор већег броја радова, коме се уједно и захваљујем на конструктивним саветима. 
њиховим правилима. Решили смо да питања не буду превише захтевна да се испитаници не би повукли из учешћа у анкети. Постављена су следећа питања: да ли је испитаник чуо за Хришћанску назаренску заједницу, ако је чуо од кога, у ком контексту, да ли у породици има неког припадника назарена, да ли је ова заједница активна у његовом/њеном месту боравка, да ли је упознао неког назарена, који је утисак су му оставили, с којом верском заједницом су најсличнији, по мишљењу испитаника, да ли је присуствовао неком њиховом окупљању, да ли су чланови назарена само Срби или има и других нација, да ли су присутни само у Србији, којим деловима и/или и у инстранству. Потом су уследила питања која су захтевала виши степен упућености - како се зову „свештеници“ код назарена, да ли су упознати како назарени називају своју „цркву“ - зграду у којом се врше службе, да ли мушкарци иду у војску, какве су им породице (велике, мале или им је то питање небитно), и на крају су била три више културолошка и социолошка шитања: да ли бисте желели, ако нисте, да упознате неког назарена и да сазнате нешто више о њима, потом - да ли бисте им поставили неко питање и као последње да ли бисте им нешто поручили, посаветовали их или им предложили.

Наша идеја је била да се стекне једна општа слика о информисаности околине о Хришћанској назаренској заједници, није се ишло на масовност, донекле се примењивао елеменат селективности због жеље да се обухвати различит профил људи, са узрасног, полног и образовног становишта.

Највише учесника анкете је било у узрасној групи од 30 до 40 и од 40 до 50 година, најмање преко 50 и до 30 година. Подједнак број анкетираних је било мушког и женског пола а што се тиче школске спреме више је било факултетски образованих испитаника.

Првобитна очекивања о резултатима анкете су била следећа: наша прва и најважнија претпоставка је била да ће половина или бар приближна половина испитаника имати одређени релевантни степен сазнања о назаренима, бар у неколико сегмената; потом смо очекивали да ће они са високим образовањем бити заинтересовани за учешће у анкети, за питања, као и за ширење сазнања о различитим религијским погледима на свет и у нашем случају о назаренима и контакту са њима. 
Исто тако смо претпостављали да ће рођени и одрасли у Војводини и у местима где су традиционално било јаке и бројчано велике назаренске заједнице више знати и имати позитивнији став о њима.

\section{Резултати анкете}

Резултати анкете су показали да пол, узраст и степен образовања нису имали значаја за квалитет и квантитет одговора, једино што се истицало су две следеће ствари: да ли у близини или у месту/граду у ком испитаници живе постоји назаренска заједница (или живе назарени у блиском комшилуку) или не (они који имају у комшилуку или у свом месту пребивалишта назарене - они показују виши степен сазнања без обзира на школску спрему) од осталих испитаника једини који су показали сврсисходна сазнања су они испитаници који имају блиске или даље рођаке назарене. Истини за вољу ниједан испитаник није имао негативан однос према назаренима, нити је имао лоша сазнања о њима, напротив, чули су за них (нису прецизирали од кога и на који начин) у позитивном контексту, али нису прецизирали у ком. У вези са тим, наша очекивања су била да ће добар глас о њима бити израженији, али очигледно је да бледе успомене на њих и њихове особине (у ранијим временима се о назаренима прво говорило кад их неко помене - поготово од оних који их више познају и са њима послују углавном је о занатлијама била реч - они су поштени, то је била прва асоцијација, потом - вредни, затим да имају много деце и да жене носе мараме и сукње). У данашње време се те асоцијације полако губе. Интересантан је и одговор на питање са којом заједницом имају највише сличности, по мишљењу анкетираних - насупрот очекивањима да ће рећи са протестантима, одговори су у већини случајева били - не знам, а неколико испитаника је одговорило са Амишима, што нас је веома изненадило, будући да су Амиши везани за подручје Америке (иако су и они настали у Швајцарској) и нема их на нашим просторима. Једно од тумачења би могло да буде да врлински живот назарена и нека врста повучености из света и световног живота подсећа на тематику америчких филмова 
о Амишима. Док их једна особа поистовећује са суботарима, који су, такође, једна од протестантских деноминација.

Оно што је нас као истраживача посебно занимало је питање о сазнањима у вези са организовањима неких догађања у цркви или верској заједници чији су чланови (без ограничења) испитаници и да ли у њима учествују. Резултати анкете су показали да је само неколико испитаника набројало догађаје које њихова црква, верска заједница, организује а ниједан испитаник традиционалне цркве не учествује у њиховом организовању. Са социолошког и религиолошкох аспекта посматрано, то су поражавајући резултати, што може довести до закључака да су чланови традиционалних хришћанских цркава отуђени од цркве, једни од других и не учествују у хришћанској „саборности“ (осим на религијским службама) која је једна од најважнијих одлика хришћана. С друге стране - назарени још увек негују саборност у најбољем смислу речи и то делима - активно и материјално учествују у заједничким активностима ${ }^{29}$, а и помажу свима у нужди ${ }^{30}$.

\section{Закључак}

Приметили смо да назарени одржавају свој верски и породични континуитет углавном у иностранству, док се на овим просторима полако осипају и улазе у заборав још од доба Југославије.

У временима најтежих искушења и константних прогона, број назарена у Србији (углавном у Војводини) је био стабилан или чак у узлазној линији, а од почетка 21. века контстантно је у паду. Објаснити узроке пада бројности није лако. Један од узрока би, свакако, био и велико исељавање назаренских породица на запад, углавном у Аме-

29 Нпр. чланови заједнице одвајају новац или/и припремају заједничке оброке кад долазе гости из других места или иностраства или, као што је случај у Америци, кад се окупљају недељом, заједнички ручају и сваки члан је с времена на време у обавези да припрема оброке и/или учествује материјално у тој припреми; потом обилазе болесне чланове, помажу им, организују превоз на службе, примају децу верних на школовање, и сл.

30 Америчка назаренска заједница из Калифорније учествује у донацијама пострадалим у поплавама у Обреновцу, у санацији кућа, од 2014. 
рику. Исељавања су почела после Првог светског рата, а настављена су до данас. У Америци су се добро уклопили у средину и организовали, будући да су тамо верске слободе доведене на висок ниво, те у назаренским скупштинама има много младих верника, а економски услови омогућавају многочлане породице (исти случај је и у Немачкој).

Не можемо рећи да се Краљевина СХC а и касније државенаследнице нису огрешиле о ове скромне, повучене, моралне и радне своје држављане. Суровост коју је држава показивала према назаренима а потом и црква, нису у хришћанском маниру и европском духу, а по данашњем речнику бисмо могли рећи да је то била „прекомерна употреба силе“. И како се и данас миграције настављају разумљива је бојазан за будућност не само назарена него и људског потенцијала државе у целини. Свакако не импонију ни резултати анкете у којима се бележи висок степен незаинтересованости окружења за упознавање и прихватање различитости својих комшија и познаника назарена.

У разговорима са људима чији су родитељи и чланови уже или шире фамилије били назарени, осећа се једна врсте сете што их родитељи или рођаци нису више упутили у назаренску догматику и историју вере, али примећујемо да доминира велико поштовање према њиховим подвизима, устрајности у вери и непоколебљивој снази њихове вере. Ако бисмо и ово разматрали могли бисмо претпоставити да родитељи нису дозволили себи да децу оптерете веома тешким бременом различитости, изолованости и одрицања, него су деци оставили избор да се сами определе, да у себи чују глас и позив Бога да се преобрате или да га не чују.

Будући да су строга дисциплина, моралност, радна етика и помоћ ближњем главне особине сваког назарена од давнина до данас, све је теже живети у оваквом свету као назарен или као хришћанин, свеједно.

Можемо слободно рећи да је судбина назарена на овим просторима веома неизвесна, али и судбина других „правих“ хришћана. Да ли ће назарени наћи снаге у себи да се некако обнове и реформишу, бар донекле крену у сусрет новом времену, остаје нам да видимо и да се надамо јер би губитком представника ове верске заједнице 
и цела заједница људи на овом простору изгубила део себе, своје и породичне историје.

\section{Литература}

Алексов, Бојан. Назрени међу Србима: верска трвења у јужној Угарској и Србији од 1850. до 1914. Београд: Завод за издавање уџбеника, 2010. Штампано.

Ђурић-Миловановић, Александра. „Мултикултурализам и религијски плурализам: Румуни назарени као мањина мањине у Војводини“. Религија и толеранција, Вол. VIII. Број 14 (2010): 357-374. Веб. 12. мај 2018.

Ђорђевић, Сања. Хришћанска назаренска заједница. Ниш: Пунта, 2003. Штампано. Константиновић, Стеван. Приче о Русинима. Шид: Гастромаркетинг, 1995. Штампано. Максимовић, Зоран. Змајево назаренство. Београд: Штампарија Саве Раденковића и брата, 1911. Штампано.

Слијепчевић, Ђоко. Назарени у Србији до 1914. године. Београд: Југоисток, 1943. Штампано.

Bjelajac, Branko. O verujućim u Hrista, progon nazarena u Srbiji. Beograd: Centar, 2015. Štampano.

\section{Dragana Savin}

\section{COMMUNITY NAZARENE CHRISTIAN IN SERBIA}

\section{Summary}

In this paper we deal with Protestant domination, registered in Serbiaas the Church of the Nazarene, and is known as the Nazarenes. We are familiar with the emergence of this religious community, the expansion in this region, its members, the rules that adhere to members, the most important dogmatic principles that they respect, and the repressions they suffered from the state. We also analyze the findings of the wider community about Nazarenes, based on the conducted survey.

Key words: Community Nazarene Christian, Nazarene, religious community, dogmatic, survey, Serbia 